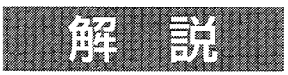

\title{
エステティックデザイン 一潜在する感性の形状化一
}

\author{
Aesthetic Design \\ -Externalize Latent Kansei-
}

\section{執筆者プロフィール}

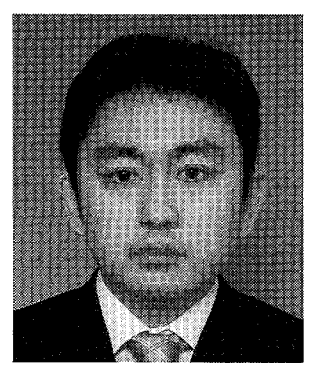

○2004年東京都立科学技術大学博士課程修了, 博士 (工学), 同年, 東京大学助手. 2008 年 より現職

○研究・専門テーマは, 感性設計学, 設計工学, デザイン学

(2)正員, 東京大学大学院工学系研究科 講師 (T113-8656 東京都文京区本郷 7-3-1） E-mail : hide@mail.design.t.u-tokyo.ac.jp)

\section{柳澤 秀吉} Hideyoshi YANAGISAWA

\section{1. はじめに}

製品の「良さ」を決定する要因は，大きく二つに分類す ることができる。一方は，製品仕様として記述できる性能 や機能である。他方は，本稿で取り上げる形の美しさのよ うに，製品仕様としての記述が困難な要因である。後者の 要因は人の感性によって評価されるため, 以下では「感性 品質」とよぶ ${ }^{(1)}$. 感性品質は, 本特集の夕イトルにある「心 を豊かにする」効用を使い手に提供する。心の豊かさ，す なわち精神的な要求は，物理的にモノがあふれる現在に扮 いて急速に高まっている，また，画一的な大量生産品を受 け入れてきた消費者は, 徐々に独自性の強い製品やカス夕 マイズに関心を高めてきている，最近では，インタネット を介して消費者が製品づくりに参加することが可能な仕組 みも出現し始めている ${ }^{(2)}$.

以上の状況を背景として，本稿では，消費者自身が感性 品質に対する要求を能動的に外在化し, 設計者に伝達する ための支援技術について紹介する，具体的には，個人の美 的感覚に基づくイメージを形状化するシステムについて紹 介する. 眼鏡フレーム形状, 自動車のアウトライン形状, 容器の形状などへ適用した事例について述べる.

\section{2. デザインとアートの違い〜顧客要 求の把握}

本稿タイトルにある言葉「デザイン」は多様な意味に用 いられるため，まず，アートとの違いからデザインに対す る筆者の認識について述べたい，アートは，主に作り手の 内面を表現することが目的である。いっぼう,デザインは, 受け手（顧客）のためにモノを設計することが主目的であ る.つまり, 受け手 (顧客) の内面に存在する要求をモノ として実現することがデザイナの仕事であると考える.

顧客の要求は, 数值化可能な性能たけでなく, 感性品質 も含む，すでに述べたように，感性品質は，感性の多様性， および主観性の問題から客観的な記述が困難である.では, 顧客は自身の内面に存在する感性品質に対する要求をいか に外在化してデザイナ（設計者）に伝えるのか？－ その 方法は，二つ考えられる。一つは，「シャープな」，「躍動 感のある」などの, イメージの印象をあらわす言葉（主に 形容詞）を用いる方法である ${ }^{(3)}$. これらの言葉は,「感性語」 とよばれている，感性語はあいまいで主観的であるから， 感性語が製品のどの特徵とどのように関係しているかを調 べる必要がある，感性工学などの分野で行われている研究 の多くは, 感性語と製品属性との関係を定式化する試みで ある。

いっぽう，感性語で表現できないイメージは，言葉を介 さず直接的に具体化する必要がある，たとえば，製品の形 状が対象である場合，イメージする形状を直接スケッチさ せることである。しかし，顧客に絵心や表現力が望めない 場合が多い，そこで，筆者らは顧客のイメージを形状化す る支援技術の開発を行っている，以下では，そのいくつか の方法について紹介する.

\section{3. センタ センクティブ・デザインプロ}

顧客自身が，頭にあるイメージを直接描くことは難しい かもしれないが, 複数のサンプルを自身のイメージと照ら し合わせて評価することは可能である。また，イメージ自 体が明確でない場合は，種々のサンプルを見ながらイメー ジを固める。これらを考慮すると,ユーザ（顧客）のイメー 
ジを形状化するシステム像は，たとえば，次のプロセスを とることが望ましい.

(1)システムが, 複数のサンプル（形状）をユーザに提示 する. (2)提示されたそれぞれのサンプルについて，ユーザ が，自身のイメージと近いか否かを評価する。(3)ユーザの 評価を反映させた新たなサンプルを作成し，ユーザに提示 する. (4)(2)扔よび(3)を，ユーザが満足するサンプルが得ら れるまで繰り返す。

以上のプロセスは，店員と客のやりとりに似ている，店 員は客の反応を見ながら商品を勧める。このプロセスを繰 り返すことで, 客のイメージする商品を徐々に絞り込む.

優れた店員は, 顧客の反応を的確にくみ取り, 外れの少な い商品を勧めることができる。これと同様に，サンプルに 対する評価から，いかにユーザのイメージと近いサンプル を生成し提示するかが課題となる。つまり，上記のプロセ スに抢ける(3)のフェーズが技術的な課題となる。

\section{4. 生物の進化を模擬した形状生成}

自然界における生物の進化は，自然淘汰のメカニズムに 従うとされている，すなわち，環境に適応する生物種が高 確率で子孫を残し，環境に適合しない生物種は淘汰される。 この自然淘汰のメカニズムを, 前述した形状生成のプロセ スに当てはめると次のようになる，すなわち，エーザのイ メージが環境に, サンプル形状が生物種に, サンプル形状 のパラメータが生物種の遺伝子に，ユーザの評価が環境の 適合度に，それぞれ対応する。

ユーザのイメージ (環境)により適合した形状サンプ ル（生物種）の特徵（遺伝子）を継承した新しい形状サン プル（次世代の生物種）を生成する。図 1 に, 眼鏡フレー ム形状を例とした模式図を示す。これにより，上記プロセ スの(3)を実現する。自然淘汰のメカニズムを人のあいまい なイメージの具体化に応用した計算機支援の方法は, 対話 型進化計算法 (Interactive Evolutionally Computation：以下, IEC ${ }^{(4)}$ とよばれている.

IEC を眼鏡フレーム形状のデザインに応用した例を紹介 する(5)，眼鏡は個人に特化した製品である。好みや顔との マッチングをふまえて，顧客は自身のイメージと適合した フレームを求める，店舗に並ぶ多種多様な製品の中から自 身のイメージに合うものを探す，あるいは自身のイメージ どおりの製品をオーダメイドで作る際，イメージを客観的 に表現する必要がある.

そこで, IECを応用して, 眼鏡フレーム形状に対する顧 客のイメージを直接的に形状化する支援システムを構築し た，図 2 に，システムの概観を示す。システムを起動する と, 複数の眼鏡形状のサンプルが提示される. ユーザは, サンプルのそれぞれを，自身のイメージと照らし合わせて 評価し 5 段階で得点化する。この得点を適合度として, 適 合度の高い形状サンプルの特徵を継承する新しい形状サン プルを提示する.この操作を繰り返すことで, 最終的にユー ザのイメージに合致する形状へと収束させる。

眼鏡フレームの形状は, 図 3 に示すように, スプライン 曲線から構成されている. 図 3 の矩形領域の各コーナから

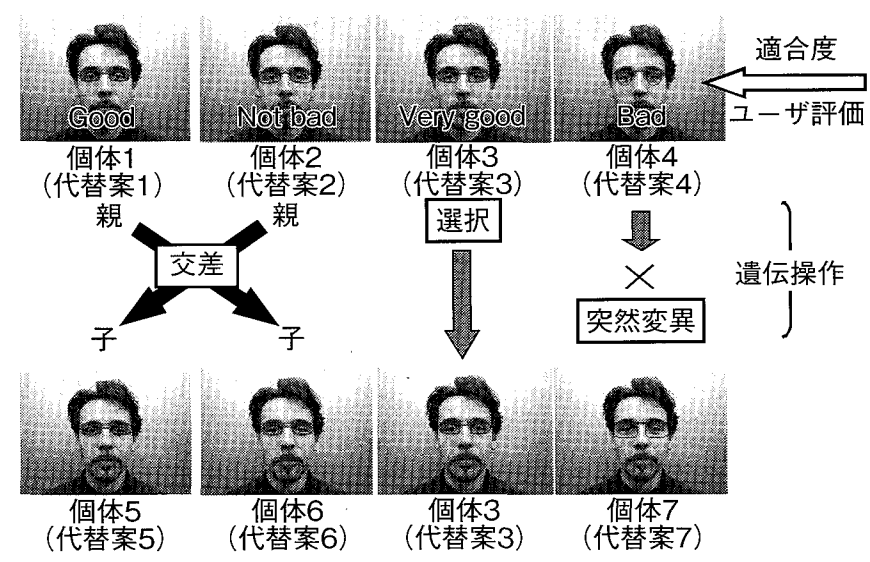

図 1 デザイン形状の自然淘汰

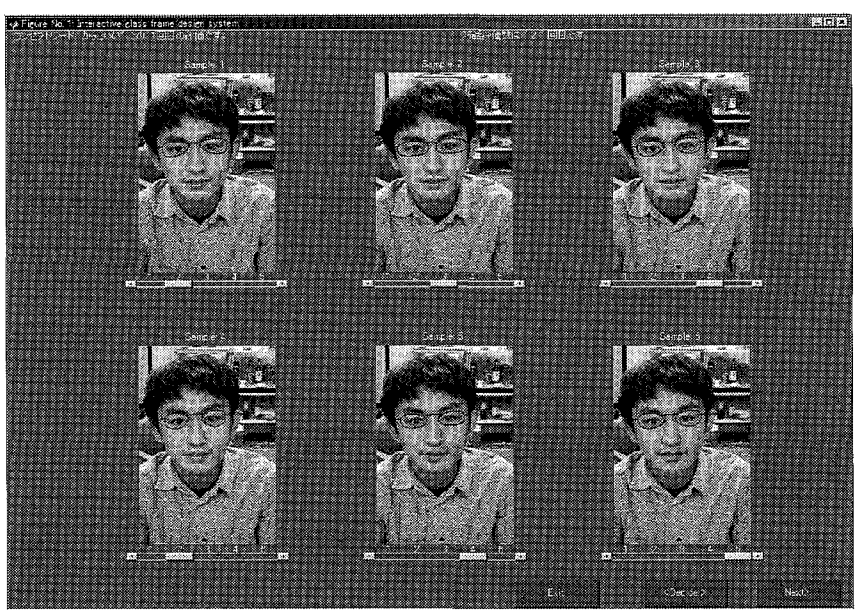

図 2 眼鏡フレームのデザインシステム

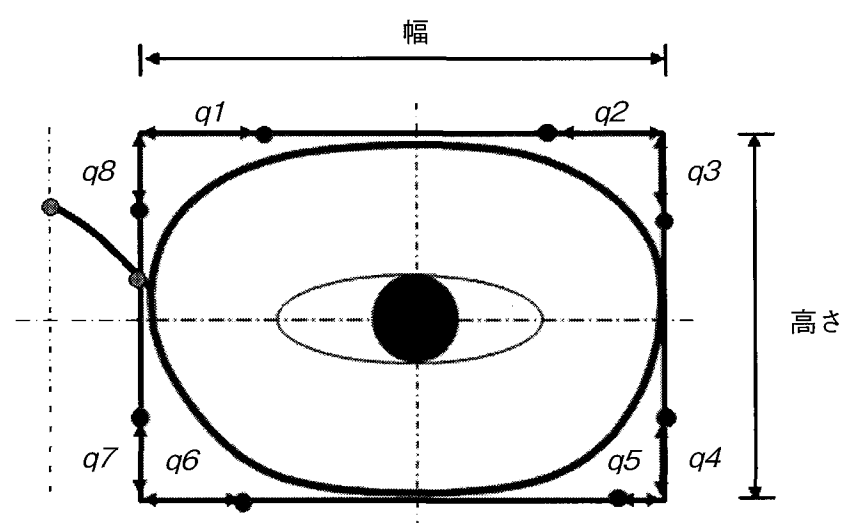

図 3 眼鏡フレームのパラメトリックモデル

スプライン曲線の各制御点までの距離と, 矩形領域の高さ, および幅をパラメータとしている.これらのパラメータが, 各形状サンプルを生物種とした際の遺伝子となる。

次世代の形状を生成する方法は, 選択, 交差, および突 然変異の三つのオペレータにもとづいている。まず，ユー ザの評価值にもとづく確率で親となるサンプルを選択す る. 次に, 選択した親のサンプルのパラメータを相互に交 換した新しいサンプル（子）をつくる，これによって，適 合度の高いサンプルの特徵が引き継がれる，最後に，ある 確率で, 一部のパラメー夕に乱数を挿入する。これを突然 
表 1 色を例とした属性表

\begin{tabular}{c|c|c|c|c}
\hline \hline 色 & 明度 & 彩度 & 色相 & 好み \\
\hline 1 & 0.1 & 0.8 & 0.5 & 好き \\
\hline 2 & 0.9 & 0.1 & 0.3 & 嫌い \\
\hline 3 & 0.5 & 0.7 & 0.8 & 嫌い \\
\hline 4 & 0.6 & 0.3 & 0.9 & 嫌い \\
\hline
\end{tabular}

表 2 色 1 の他の色サンプルと比較した識別度行列

\begin{tabular}{c|c}
\hline \hline Bad / Good & 識別度 \\
\hline 色1-色 2 & $\langle-0.8,0.7,0.2\rangle$ \\
\hline 色1-色 3 & $\langle-0.4,0.1,-0.3\rangle$ \\
\hline 色1-色 4 & $\langle-0.5,0.5,-0.4\rangle$ \\
\hline
\end{tabular}

変異とよぶ，突然変異を行う理由は，局所解に陥らないた めである. 本システムの有効性を検証するため, 被験者に よる評価実験を行ったところ，8回前後の繰り返しでイ メージする形状が得られることがわかっている.

\section{5. 注目特徵を予測する}

IECでは，次世代へ継承される特徵（パラメータ）は交 差にもとづきランダムに選択されていた．しかし，ユーザ は,必ずしもすべてのパラメータを等価に評価しておらず, 無意識的にある部分に注目して全体を評価している。これ は，認知科学に扔ける選択的注意の知見としても説明され ている.

そこで，筆者らは，IECに代わる新しいアルゴリズム， 対話型縮約進化計算法 (Interactive Reduct Evolutionally Computation：以下，IREC）を考案した ${ }^{(6)}$ IRECは，ユー ザが注目している部分の特徴を推定し，その特徴に寄与す るパラメー夕を優先的に継承する仕組みを有する。 注目特 徵の推定方法には, ラフ集合理論の縮約計算法の考えを忘 用している，縮約（Reduct）とは，複数の対象を分類した 際，その分類を説明する対象の属性の最少の組合せを意味 する。つまり，複数のサンプルに対して，ユーザが，複数 のサンプルをイメージと合う，合わないに分類した際，そ の分類に寄与する属性の最少の組合せが縮約である。この 場合，縮約はイメージに合うか合わないかを分ける特徴で あるから, 評価の際にユーザが注目している可能性が高い． そこで，縮約を推定された注目特徴とすることにした，

縮約の計算法について, 簡単な例を用いて紹介する。今, 表 1 に示すように 4 種類の色がサンプルとして提示されて いるとする，色は，それぞれ，明度，彩度，および色相の 三つのパラメータから構成されている。 ただし，值は 0 か ら 1 に正規化してある. この四つの色サンプルに対して， 色 1 が好き，それ以外は嫌いと評価したとする。このとき の, 好みの判断の注目点を, 色のパラメータから説明した い，縮約計算では，まず好きと選択された色とそれ以外の パラメー夕同士を引き算し，表 2 のようにまとめる。これ
コンセプト:エレガント

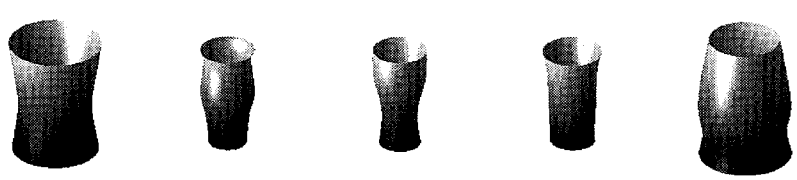

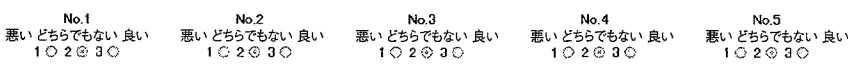

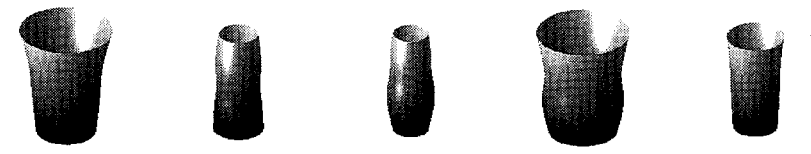

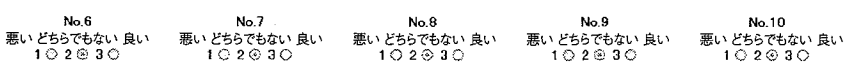

図 4 容器の形状のデザイン

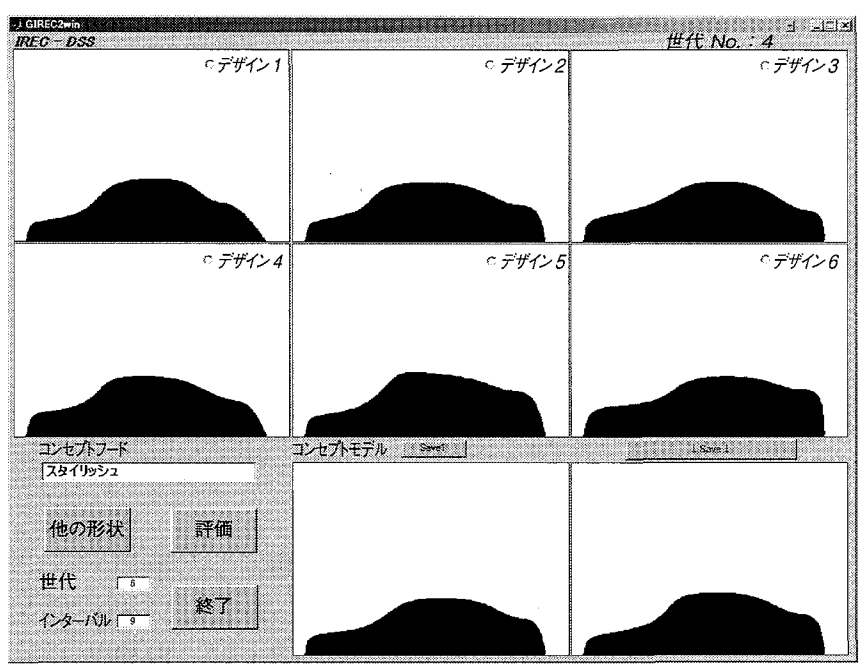

図 5 自動車のアウトライン形状のデザイン

を，識別行列とよぶ．また，その要素は，好きから嫌いへ の識別の度合いを意味するため，識別度とよぶ.

コーザがすべてのパラメータを同時に注目していないこ とを仮定し, 識別行列の同一行の要素を論理和で結合する. たとえば, 色 1 が色 2 から分けられる理由は, 識別度 0.8 で明度が 0.1 ，もしくは識別度が 0.7 で彩度が 0.8 以上，も しくは識別度が 0.2 で色相が 0.5 以上だから，ととらえる。 次に，色 1 は，色 2，3，4のすべてから識別されなけれ ばならないので, 論理和で表現した各項目を論理積で結ぶ. これを，式で表現すると，（0.8/（明度＜0.1）マ0.7/（彩 度 $>0.8) \vee 0.2 /($ 色相 $>0.5) \wedge(0.4 /($ 明度 $<0.1) \vee 0.1 /$ $($ 彩度 $>0.8) \vee 0.3 /($ 色相 $<0.5)) \wedge(0.5 /($ 明度 $<0.1)$ $\vee 0.5 /($ 彩度 $>0.8) \vee 0.4 /($ 色相 $<0.5))$ となる。ただし, $d /(A>x)$ は識別度 $d$ で属性 $A$ が $x$ より大きいことを意

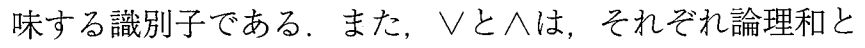
論理積をあらわす，以上の式を展開して整理すると，最小 縮約は， $0.4 /($ 明度 $<0.1) \vee 0.3 /(($ 彩度 $>0.8) \wedge($ 色相 $<0.5) ＼vee \vee 0.2 /($ 色相=0.5）となる.つまり, 色 1 を選ん だ理由として，明度が 0.1 以下，もしくは彩度が 0.8 以上 
かつ色相が 0.5 以下，もしくは色相が 0.5 , の三つの可能 性が得られた。これは，ユーザがどのパラメー夕に注目し て好き嫌いを判断したかの候補を意味する，IRECでは， ユーザの評価から縮約を計算し，その縮約をユーザが注目

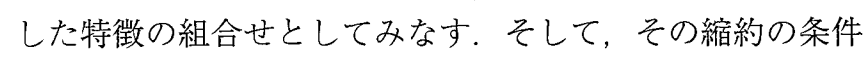
を満たすように，次世代の形状を生成する。

IREC を, 図 4 に示すような容器の形状デザインに適用 したそそして，IECによるシステムと，被験者による比較 実験を行った，その結果, 収束の繰り返し数と, 得られた 形状解の満足度に有意な差が確認された。 また，ユーザが 注目していた特徴と, 形状の生成に利用した縮約に一致性 が確認された。これによって, 縮約がユーザの注目する特 徴をよくあらわしていることが明らかとなっている.

\section{6. 大域的な形状特徵量の導入}

これまで見てきた眼鏡フレームや容器の形状は, スプラ イン曲線の座標位置など, 部分のパラメータのみを扱って きた。しかし，人間は部分の形状特徵だけでなく，「全体 的に複雑な形」といったように全体的な形状の特徵をとら えている場合もある。このような全体的な特徵を, ここで は大域的特徴とよぶことにする。

筆者らは，大域的特徵を定式化し，IRECのパラメータ とすることで，より人間の形状認知に適合したシステムへ と発展させる試みを行っている(7). 自動車ボデーのサイド ビューのアウトライン形状を適用対象としたシステムの概 観を図 5 に示す。本事例では，七つの大域的特徵量を抽出 した. すなわち、シャープネス・ソフトネス, 曲線の加速 度, 形状の複雑さ, 形状の凹凸度, ボリューム, 重心, お よび傾きである.

シャープネス・ソフトネスとは，人が形状から認知する 物体の柔らかさを意味する。一般的に, 丸い形状は四角い 形状よりも柔らかい印象を受けやすい。連続的な曲線から 構成される形状においては，曲率の最も大きい箇所が柔ら かさの印象に影響を与えやすいと考えられる. 本研究では, 連続曲線により構成される形状の最小の曲率半径をシャー プネスと定義し，その逆数をソフトネスと定義している.

曲線の加速度とは，曲率の変化の度合いを意味する．加 速度が大きければ，急激に曲率が変化する曲線となる。本 研究では, 曲線の各凹凸において, 最大の加速度を代表值 とし，その平均值を曲線の加速度と定義している.

曲線で構成される形状においては, 形状の複雑さと, 曲 率のエントロピーとの定量的な関係が確認されている ${ }^{(8)}$. エントロピーは, 情報の局在の度合いをあらわす指標であ る。したがって，曲率のエントロピーは曲率の隔たりを意 味する。この值が増加するほど，曲率の隔たり程度が増し 複雑な曲線となる。「複雑さ」は他の大域的特徵量に比べ, より主観的な印象を直接説明する形状特徴量の一つであ る。また，非線形的な特徴をあらわす，本研究では，これ を引用し大域的特徵量の一つとして導入している.

部分的な特徵のみをパラメータとした場合と, 大域的特 徵量をパラメータに含めたIRECの場合について, 被験者 による評価実験を行った，その結果，解の収束の早さに有

意な差が確認された。多くの被験者において，まず大まか な形状を作成し, その後, 細部に注目して形状を調整する 過程が確認された. 大域的特徵量を導入することにより， 初期の大まかな形状への収束を早めることが可能になった と考えられる。

\section{おわりに}

本稿では，計算機が生成する複数の形状案に対する主観 評価の反復によって，製品形状に対する顧客のあいまいな 要求イメージを形状化する支援技術について紹介した。 こ れらは, 今後, 個人化・多様化が進む製品設計において, 顧客のあいまいな感性要求の把握支援に応用可能である. 現在, 筆者らは, 想定内の要求イメージの外在化だけでな く, 顧客自身も気づいていない潜在的な感性要求を抽出す る方法について検討している界(10). その基本的な考え方 は, 同一の形状に対する異なる視点を他者間で相互参照し, 自身が想定しえない視点を抽出する方法に基ついている. そして，どのような視点が潜在要求の喚起に寄与するかを 実験により調査している.

現在までにわかってきていることは，頻度の低い視点の 有効性が高いこと, 拉よび同質的な被験者間でも他者の潜 在要求の喚起に影響を与える視点を提供する被験者とそう でない被験者に分か机ることである。このことは，従来の ように多量の要求調査データを統計処理するよりも, 想定 外の視点を持つ少数の顧客を捜し出し, 彼らの要求を抽出 する新しい方法が必要であることを示唆している.今後は, 他者の潜在要求を喚起させる想定外視点を抽出する方法に ついて検討していきたい.

（原稿受付 2008 年 9 月 22 日）

文 献

（1）柳澤秀吉, 感性と設計, 機械の研究, 59-1 (2007)，191-197.

（2）たとえば，空想無印，http://www.cuusoo.jp/muji/

（3）柳澤秀吉, 感性の多梯性を考慮した感性品質の定量指標化手法 : 製品の音質設計への適用，日本機械学会誌，110-1069 (2007)， 57.

(4) Takagi, H., Interactive Evolutionary Computation: Fusion of the Capacities of EC Optimization and Human Evaluation, Proc. IEEE, 89-9 (2001), 1275-1296.

(5) Yanagisawa, H. and Fukuda, S., Development of Interactive Industrial Design Support System Considering Customer's Evaluation: Shape Design of Eyeglass Frame, JSME Int. J., C, 47-2 (2004), 762-769.

(6) Yanagisawa, H., Fukuda, S., Interactive Reduct Evolutionary Computation for Aesthetic Design, Trans. ASME, J. Computing and Information Sci. in Eng., 5-1 (2005), 1-7.

（7）柳澤秀吉・福田収一，大域的特徴量にもとづく対話型縮約進化 計算（意匠設計における曲線形状処理への適用）, 日本機械学会 論文集, 70-699, C (2004), 322-330.

(8) Matsuoka, M., Sape-generation method using currature entropy, KANSEI Engineering International, 1-4 (2000), 11-18

（9）柳澤秀吉・村上 存, 視点共有型意匠形状生成システムの開発 (異質な視点による顧客の潜在感性の喚起), 日本機械学会論文 集, 73-735, C (2007)，220-227.

（10）柳澤秀吉・村上 存, 感性設計における顧客の潜在的な評価視 点の抽出とその効果（他者間での視点の相互評価と想定外視点 の抽出), 日本機械学会論文集, 73-735, C (2007), 228-236. 